\title{
The Turning Point: The American Ceasefire Initiative between Israel and Egypt, August 1970
}

\author{
By Moshe Gat*
}

\begin{abstract}
The ceasefire of August 1970 proved the United States' ability to set the wheels of the peace process in motion. The USSR did not partner with it en route to the ceasefire, and, in fact, was against it. The ceasefire between Israel and Egypt may be viewed as a turning point in Egyptian-American relations. It was Nasser who had led the United States to intervene in the peace process, without the help of the Soviets, creating an opportunity for the return of US clout in Egypt, after it had reached an unprecedented low during and after the Six Day War. In fact, after the ceasefire the United States was slowly becoming a major axis in the pollical process. For Egypt, the United States was the only power that would help in returning the occupied lands.
\end{abstract}

\section{Introduction}

The end of the second world war in 1945 marked a new era in the international relationship known as the cold war. This war was characterized by power struggle between the Soviet Union (USSR) and the United States and its allies. On the one hand the USSR sought to expand its influence around the glove and on the second hand the US adopted a policy of containment, the purpose of which was economic and military assistance to any country threatened by the Soviets. The struggle between the great powers first focused on Europe. In this part of the world the USSR passed most of Eastern European countries under its control as well as over East Germany. The struggle then shifted to the Far East and manifested in 1951 war in Korea. This war ended in 1953, but its result were two Korean states- the South and the North.

From the early 1950s, the USSR began to increase its penetration into the Middle East. The arm deal between the Soviet Union and Egypt in 1955, known as the Czech deal, marked the beginning of Soviets influence. In subsequent years, the USSR provided Egypt with economic, military, and political assistance and became the main arms supplier of Egypt and Syria.

On the other hand, Israel was supported, to one degree or another, by the United States, Britain and France, powers that also provided it with modern weapons. Just as Europe and the Far East were part of the international power struggle, so the Middle East became part of the cold war. ${ }^{1}$ The war that broke out on 5 June 1967 between Israel and its neighboring countries - Egypt, Syria, and Jordan - known in historiography as the Six Day War, was among other things, a product of the cold war. During the war, from June 5 to June 10, the Arab armed forces suffered a crushing defeat by the hands of the Israeli military, which

*Professor Emeritus, Bar Ilan University, Israel.

1. Lundestad, East, 32-46, 81-82, 118-119. 
proceeded to seize the Sinai Peninsula and Gaza Strip from the Egyptians, the Golan Heights from the Syrians, and the West Bank from the Hashemite Kingdom of Jordan.

Egypt blamed the United States and United Kingdom for aiding Israel during the war. Egyptian President, Gamal Abdel Nasser, announced that there was clear evidence of an imperialist conspiracy with the enemy, and in response, severed Egypt's diplomatic relations with the United States. This marked an unprecedented low point in the relations between the two countries since the Egyptian Officers' Coup in 1952.2 When the June war ended, American clout in the region gradually eroded, whereas that of the Soviet Union increasingly grew despite the defeat of its allies, Egypt and Syria. In fact, one might say that the Soviets had not been this influential since the Egyptian-Czechoslovak arms deal of 1955. Following the war, the Soviets were active on two fronts:

a. Military aid to compensate for what had been lost during the war, and a reorganization of Egyptian and Syrian armed forces.

b. Political support in the form of adopting the Arab standpoint whereby any negotiation must be preceded by an Israeli withdrawal from the territories occupied during the war. ${ }^{3}$

In contrast to this position, the Israeli leadership assumed that the harsh blow it had dealt the Arabs would lead them to the realization that they had to join the negotiating table in order to pursue the resolution of the conflict. ${ }^{4}$ It viewed the territories as a bargaining chip with an underlying security and existential basis, regardless of any historical or religious one. ${ }^{5}$ Washington was also of the opinion that the Arabs' crushing defeat had created suitable circumstances for the resolution of the Israeli-Arab conflict, and the establishment of a permanent agreement for the resolution of the refugee problem. ${ }^{6}$ In an address given on 19 June President Johnson set several principles for the resolution of the conflict: Israeli withdrawal from Arab land should only follow a peace accord that includes, inter alia, respecting the political independence of neighboring countries, free passage, and a just solution to the refugee issue. He did not rule out possible border modifications between the parties. These

2. Sharnoff, Nasser's Peace, 31-33; Jesse Ferris, Nasser's Gamble, 261, 263. See also, Gat, Britain, and the Conflict in the Middle East, 16-17, 26.

3. Sharnoff, Nasser's Peace, 57.

4. Haber, Today War Will Break Out, 258-259; Pedatzur, Triumph of Embarrassment, 28.

5. Israeli State Archives (ISA), Jerusalem, A-10/6304, Prime Minister's Files, 9 June 1967; Eban, Memoirs, 430; Rabin, Service Notebook, vol. 1, 226-227.

6. The National Archive, Kew, London (TNA), Foreign Office (FO), 17/522, Wilson to Johnson, 15 June 1967; Prime Minister's Office (PREM),13/1620, Record of a Telephone Conversation, 7June 1967, and FO to Certain Missions, 16 June 1967; Rostow, Peace in Balance, 250-255. 
principles served as the basis for US policy in every negotiation effort between Israel and its neighbors. ${ }^{7}$

On 22 November UN Security Council reached Resolution 242, whereby just and sustainable peace was to be established, and include withdrawal from the territories occupied during the war, agreed borders between Israel and its neighbors, the cessation of the state of belligerence, an international effort to resolve the refugee problem, and free passage in international waterways. According to the resolution, a special envoy was to be appointed by the UN General Secretary and sent to the region without delay to help reach a peace agreement. ${ }^{8}$ Gunnar Jarring, the special envoy, attempted to advance an agreement primarily between Israel and Egypt throughout 1968, but to no avail. ${ }^{9}$

A new US administration was introduced into this political stagnation, headed by President Richard Nixon, who entered the White House on January 20, 1969. Unlike its predecessors, this administration was determined to promote a peace agreement between Israel and its neighboring Arab countries. President Nixon attributed great importance to the Middle East due to its strategic significance, viewing it as a dangerous area, especially after Nasser launched a war of attrition against Israel in March 1969, that could lead to a conflict between the two superpowers. ${ }^{10}$ US Secretary of State, William Rogers, assumed that the continued Israeli control of the territories harmed US interests. The unrelenting stagnation increased Arab disgruntlement, fed extreme forces in the Arab world, and facilitated the expansion of Soviet impact. It also created tension between Israel and its neighboring countries that could potentially have escalated to hostilities. Thus, to refrain from further erosion in US clout, it was necessary to take immediate action to resolve the conflict. ${ }^{11}$

Rogers attempted to reach an agreed formula for the resolution of the conflict with the Soviets, but to no avail. Any idea raised that did not align with the Egyptian standpoint, i.e. total Israeli withdrawal prior to any negotiation, was rejected by the Soviets. Ultimately, Rogers formulated a plan known as the Rogers Plan, whereby Israel was to withdraw to its June 4 international border with Egypt. The Rogers Plan also included: the establishment of demilitarized zones; ensured free passage through Egypt and the canal; recognition of parties' sovereignty and political independence, as well their right to exist in peace; and

7. Shannon, Balancing Act, 64; Lyndon, Vantage Point, 303.

8. For the full text of Resolution 242 see Moore, The Arab-Israeli Conflict, 802-803.

Foreign Relation of the United States (FRUS), 1964-1968, Arab-Israeli Crisis and War, 1967, vol. 19, 930, 940-943.

9. Riad, Struggle for Peace, 78-79; Korn, Stalemate, 142.

10. United States National Archives (hereafter USNA), RG59/1821, Rogers to Moscow, 23 June 1969; Spiegel, Other Arab-Israeli Conflict,172; Stein, Heroic Diplomacy, 57; Yaqub, "Politics of Stalemate.", 37.

11. Quandt, Peace Process, 61-62, 64; Tschrigi, American Search, 57; Yaqub, "Politics of stalemate", 36; Dallek, Nixon and Kissinger, 172; Rabin, Service Notebook, vol., 1, 246. 
the resolution of the refugee problem. According to the plan, the withdrawal to the June 4 lines was to be carried out only once all required arrangements were in place as part of a signed peace accord. ${ }^{12}$ However, both parties rejected the plan. Egypt argued that it was not serious enough, but merely a vehicle by which to push it to the negotiating table from a weak position. Cairo maintained that battle was the only alternative, stating their land will be retrieved with blood and fire. Al Ahram newspaper called it a trap. ${ }^{13}$ The Israeli government thought the plan posed a danger to Israel's existence. ${ }^{14}$

\section{Soviet Involvement}

In the absence of a political solution, the Israeli government decided in early January 1970 to employ a new strategy of deep-penetration air raids in Egypt. These strategic bombings aimed to invoke Egypt's surrender and renew the ceasefire. The Egyptian armed forces were helpless against the harsh blows delivered by Israeli Air Force. ${ }^{15}$ The deep-penetration air raids had a devastating effect on the Egyptian military's morale. Instead of exhausting Israel through war, as Nasser announced he would do in March 1969, it was the IDF [ Israeli Defense Force] that exhausted Egypt. The suburbs of Egypt's capital, Cairo, had war brought to their very doorstep, as did other cities in Egypt .The US State Department was very concerned by these strategic bombings, for instead of promoting a political resolution of the conflict, they were exacerbating matters. One expression of this concern was President Nixon's announcement on January 30, 1970 that he was postponing all arms shipments to Israel and would reexamine this matter in due course. ${ }^{16}$

And indeed, on late February the Soviets began to deploy SA3 batteries around Cairo, Alexandria, and Aswan. In fact, an anti-aircraft missile belt was set up around those cities, manned by Soviet teams under Soviet command. In addition to the missile units, combat squadrons complete with operators were sent to defend inner Egyptian airspace. The forces and equipment sent merely aimed to put a stop to the strategic bombings. ${ }^{17}$ Washington argued that the arms shipments were not irresponsible. ${ }^{18}$

12. Moore, Arab-Israeli Conflict, 1024-1033.

13. TNA, FCO17/132, Record of Anglo-American Talks, 29 January 1970; Parker, Politics of Miscalculations, 138.

14. Kissinger, White House Years, vol.1, 401; Rabin, Service Notebook, vol.1, 263.

15. Gawrych, Albatross of Decisive Victory, 144; Eban, Memoirs, 459; Rabin, Service Notebook, vol. 1, 271-272.

16. Rafael, Destination Peace, 195; Spiegel, Other Arab-Israeli Conflict, 191.

17. Heikal, Secret Channels, 152; Korn, Stalemate, 190-191. For a figure on the Soviet forces in Egypt at that time see, Vitan, "Soviet Military Presence.", 552.

18. USNA, RG59/2051, Memorandum of Conversation, March 20, 1970. 
Soviet involvement was also manifest on the warfront. The Israeli Air Force's freedom of action was narrowing in light of the missile deployment. On March 20, Israeli Minister of Defense, Moshe Dayan, announced that Israel would minimize its strategic bombings, and will not attempt to assert its strategic superiority everywhere in Egypt. Instead, he stated, Israel's superiority would be limited to the canal area. ${ }^{19}$ When Egypt saw that the Soviet involvement had impeded Israel's capabilities, it heightened its attacks against Israeli forces. Military exacerbation between Israel and Egypt was ever imminent, and the Americans sought to end this mutual bloodshed, and find a way back to peace negotiations.

The US Secretary of State blamed the raids for the Soviets' involvement, and the flow of sophisticated weaponry systems and crews to Egypt. Moreover, if aircraft were to be provided, Israel could become even more adamant, making it harder to set in motion the peace process, while spurring the regional arms race, and enhancing violence. ${ }^{20}$ Rogers' assumption was that an American announcement that the supply of aircraft to Israel was postponed would not serve as reason for the Soviets to send large amounts of weapons to Egypt. He also maintained that if the Soviets wanted to renew the talks and reach a political arrangement, their position should be softened by a display of American restraint. ${ }^{21}$ And indeed, on 23 March, Rogers announced that Israel's aerial capabilities sufficiently met its needs for the time being. The US President therefore decided to suspend the shipment of aircraft. ${ }^{22}$

However, the Soviets were not interested in reaching any form of agreement on limiting arms, and particularly not with regard to a ceasefire that would motivate a peace process. ${ }^{23}$ From the Soviets point of view an arrangement based on the Rogers Plan would only benefit the United States. The State Department therefore concluded that the Soviets were not serious about a ceasefire between Egypt and Israel, were completely opposed to limiting arms, and objected to the Rogers Plan. Their policy was one of standstill and ongoing violence between Israel and Egypt, which served their purposes by "keeping the pot boiling". The Nixon administration decided to advance the peace process without the Soviets' help. There was reason to believe that both Egypt and Israel were interested in greater US involvement at the time, and in a way out of the exhausting war in which they were tangled up.

Although Egypt appreciated the Soviets' military capabilities, and their provision of weapons, equipment, and human resources to defend Egyptian

19. Bar-Siman-Tov, "Myth of Strategic Bombing.", 559.

20. USNA, RG59/2062, Rogers to Tel Aviv, 11 April 1970; Korn, Stalemate, 198-199.

21. Nixon, Memoirs of Richard Nixon, 480; Bar-Siman-Tov, Israel, 172.

22. Rafael, Destination Peace, 199; Rubinstein, Red Star, 115.

23. USNA, Nixon Files/653, SD to Moscow, 12 June 1969; USNA, RG59/1837, Memorandum for the President, 20 June 1969; Korn, Stalemate, 155; Kissinger, White House Years, vol.1, 391. 
territory, it realized that its ally lacked political skill. This great superpower, for nearly three years, since the 1967 war had ended, failed to force Israel out of the territories it occupied. Nasser acknowledged the United States' capabilities, as well as its influence over Israel. The Americans possessed the power to make Israel withdraw to its June 4 international border, as they had done following the Suez Crisis in 1957. The Egyptian President therefore opened a direct communication channel with the US administration to discuss a political arrangement. ${ }^{24}$ The opening of such channel with the Americas indicates the pragmatism of the Egyptian president, a leader who did not adhere to ideological principles. The willingness to begin a direct dialogue with Washington was a shift in Egyptian policy, for until then, all peace talks had been held between the United States and Soviet Union. But Egypt did not forego its special relations with the USSR at that time either, for it had supported it militarily, and aligned itself with its standpoint on the resolution of the conflict.

Moreover, the Egyptian leader's willingness was timely. Having the home front defended by anti-aircraft means provided the Egyptian public with a sense of security. It felt like it could withstand Israeli attacks, and even deliver a blow to the Israeli armed forces. Egypt subsequently began to employ its artillery relentlessly. Its willingness to hold talks with the US administration was not an indication of humiliation or surrender, it reflected recognition of its power, regardless of whether this was objectively true or not. ${ }^{25}$ The direct dialogue with the United States also expressed Egypt's exhaustion with the ongoing war of attrition, for despite Nasser's confidence, by that point he was looking for a way out of it.

Israel was also interested in greater American involvement, but from a different perspective. The Soviet involvement was a cause for concern, as was the US policy that suspended the supply of aircraft to it at a time when the military situation was escalating. Moreover, the war had exacerbated, and the continuous war of attrition was gnawing at Israeli society. The public was appalled by the growing number of victims and felt that the government was not doing enough to end the belligerence. Some of the young adults on the brink of being drafted into the IDF were less motivated to do so, as they saw the Israeli armed forces attempting to end the war to no avail. The toll was high, and soldiers continued to die in a war that appeared endless. ${ }^{26}$

The United States felt that the conditions created - both sides' weariness of the prolonged war, Nasser's acknowledgement of its ability to resolve the conflict,

24. USNA, RG59/2052, Rogers to London, 8 April 1970; Sadat, Search of Identity: An Autobiography, 198.

25. ISA, Hez9/6854, Rabin to Jerusalem, 28 April 1970; USNA, RG59/2052, Memorandum for Kissinger, 5 May 1970.

26. Gazit, Israeli Diplomacy, 79; Ya'acobi, Grace of Time, 87; Shem-Tov, “Golda's Missed Opportunit, 226-227. 
and the pressure exerted on Israel by its refusal to supply more aircraft - were paving the way for a new initiative that would motivate the peace process in motion.

\section{En route to a Ceasefire}

The State Department decided to begin by taking steps towards a ceasefire without the Soviets' help. The Soviets' conduct, assumed Rogers, was indicative of how the USSR was intentionally ignoring the severe and dangerous situation that resulted from its decision to take an active part in defending Egypt. ${ }^{27}$ The need therefore emerged for a limited ceasefire accompanied by preservation of the military status quo on both sides of the canal. It could also mitigate the risk embedded in an Israeli-Soviet conflict, which would increase the hazard of a conflict between the two superpowers. Hence this political initiative, which was submitted to the parties' review on 19 June. According to it: To facilitate the role played by the special envoy in the promotion of the accord, the two parties were to agree to renew the ceasefire for three months.

Golda Meir was devastated by this proposal. The ceasefire as proposed by the US provided Egypt with ninety days in which to recover from Israeli attacks, implement new weapons, and renew the fighting from an improved position, while Israel was denied aircraft shipments. What the United States were ultimately asking Israel to do was pay the price of a weaker military in return for negotiations, whereas Egypt remained free to continue with its war of attrition, and receive unlimited supply of ammunition from the Soviets. Moreover, the latter were not limited in any way in their shipments of weapons to Egypt, and they were free to keep the flow going whenever they desired. ${ }^{28}$ In short, Meir's view on the US initiative was absolutely negative.

President Nixon therefore decided to intervene to stop the Israeli government from giving a negative reply. On 21 June he sent a letter to Golda Meir emphasizing US commitment to and concern for Israel's security. He wrote that he "attached the highest importance to the effort we are making. The Soviet threat is both political and military, and our initiative is designed to meet that threat in both its aspects". He therefore asked to avoid taking "any irreversible action" by requesting that Israel refrain from being the first to respond to the initiative if its reply was to be negative. He asked Israel to wait for Egypt's answer before giving its own, so that it would not be blamed for the initiative's failure. If

27. USNA, Nixon Files/H-30, Memorandum for the President, 9 June 1970.

28. USNA, RG50/2054, Tel Aviv to SD, 19 June 1970. 
Israel were to be blamed, it would have been a major setback both for Israel and the United States. ${ }^{29}$

The Soviets disapproved of the initiative. Minister of Foreign Affairs, Andrei Gromyko, told US ambassador to Moscow, Jacob Beam, that the initiative was nothing new, and contained all the disadvantages of previous efforts. Dobrynin, Soviet ambassador in Washington, told Henry Kissinger' Head of National Security Council, that this initiative was an American attempt to take over Middle Eastern diplomacy. ${ }^{30}$ And indeed, an initiative bearing the White House seal did not serve Soviet interests, for it was a manifestation of American capabilities, an indication that none other could drive the peace process in motion.

Leonid Brezhnev, General Secretary of the Communist Party, was certainly aware that Egypt was leaning towards accepting the American proposal. He told Nasser that the US administration was taking full credit for the initiative. It was, he said, "a shrewd and cunning way" of presenting the initiative to see to it that Egypt will accept a proposal bearing the White House seal alone. Nasser may have agreed with him but said that he assumed the Israeli government would reject the offer, for accepting it would cause a domestic rift. He believed that to be the reason why Israel had, until that point, refrained from revealing its standpoint on the matter altogether. Both Israel and the United States assumed that Egypt would reject it, thus justifying the renewed delivery of aircraft to Israel. ${ }^{31}$

The issue of aircraft supply to Israel hung over the Egyptians' heads while they contemplated their response to the initiative. Moreover, he felt three months of no fighting would allow the public to breathe again after many months of war that took a heavy toll on the population. It would give the Egyptian army some time to rest and improve its capabilities, also allowing for the missile batteries to be advanced towards the western bank of the canal, for until then, the Israeli Air Force had prevented it. ${ }^{32}$ On July 22, several days after Nasser's return from Moscow, Egyptian Minister of Foreign Affairs, Mahmoud Riad, told Rogers they accepted the initiative. This move meant that Egypt had accepted its failure to achieve the goals it had set when it began its war of attrition against Israel. It also constituted a shift in Egyptian policy, that until then had demanded Israeli withdrawal from the territories prior to any negotiation. Egypt had now agreed to a ceasefire without obtaining Israel's promise of total withdrawal.

The Egyptians accepted the American offer made, and were joined by the Soviets, leaving Israel in a very difficult position. A negative response meant colliding with the administration that was doing everything in its power to

29. USNA, RG59/2065, Rogers to Nixon, 20 June 1970; Rabin, Service Notebook, vol. 1, 292.

30. Kissinger, White House Years, vol. 2, 607.

31. Riad, Struggle for Peace, 145; Heika, Road to Ramadan, 95; Sadat, Search of Identity, 198-199; Wehling, Irresolute Princes, 90-91.

32. Abdel Majid, Nasser, 176; Heikal, Secret Channels, 156; Pollock, Politics of Pressure, 77; Riad, Struggle for Peace, 144-145. 
initiate a peace process and would also harm Israeli interests. Dayan phrased it as follows: "Israel is too strong to have arrangements forced upon it, but too weak to be slipping at present into a political conflict with the US". The other front was the military one. The Soviets' entry with their missile batteries not only put a stop to the deep-penetration air raids but increased Israeli aircraft's vulnerability. On 29 July, in a collision with Soviet pilots, the Israeli Air Force intercepted four Migs. These incidents indicated that the war was expanding, highlighting the possible collision with Soviet forces on Egyptian soil. Under these circumstances, Prime Minister Meir announced the acceptance of the US initiative on August 4, preferring it to a conflict with the US administration, and the ongoing war on the canal front. ${ }^{33}$ The Israeli-Egyptian ceasefire entered into force on August 7.

The two parties' acceptance of the ceasefire initiative indicated a shift in both their policies, but first and foremost it reflected the turn taken in Egyptian-US relations. If any victory had been scored, it was scored by US diplomacy. The ability to make both parties agree without the help of any other superpower proved that the United States did not require the Soviets' assistance in igniting the peace process, was capable of having direct dialogue with Egypt, and offering the Rogers initiative as it did.

\section{Conclusion}

The ceasefire was, in this respect, a turning point. Egypt and Israel had had skirmishes since the Six Day War had ended, escalating from March 1969 onwards, after Nasser had declared a war of attrition against Israel. From August 1970, once the ceasefire agreement was signed, the Israeli-Egyptian border was quiet until October 1973, when the Yom Kippur War broke out.

From the moment the ceasefire was agreed upon, negotiations on the resolution of the conflict began between Egypt and the United States. Although Nasser had led the Americans to intervene in the peace process, it was his successor, Anwar Sadat, who wanted to turn the US into a central axis that would help Egypt regain control of its occupied territories. It was no wonder, therefore, that Sadat told the Americans early on in his term in office, in October 1970, that his country sought genuine peace that would end the bloodshed. ${ }^{34}$ The Egyptian president had indeed broadened his country's collaboration with the United States, seeking an arrangement throughout the three years leading up to the October 1973 Yom Kippur War. Following it, the United States had the parties sign a ceasefire agreement on 22 October, followed by an Agreement on Disengagement in January 1974, and a similar agreement with Syria in May that

33. Rafael, Destination Peace, 266; Shiff, Phantom over the Nile, 227.

34. Burns, Economic Aid,176-177; El Hussini, 184; Heikal. Secret Channels, 169. 
year. America's ability peaked at the signing of a peace accord between Israel and Egypt in March 1979.

\section{Bibliography}

Abdel Majid, Farid. Nasser, the Final Years. Reading: Ithaca, 1994.

Bar-Siman-Tov, Ya'akov. Israel, the Superpowers, and the War in the Middle East. New York: Praeger, 1987.

Bar-Siman-Tov, Ya'akov. "The Myth of Strategic Bombing: Israel Deep Penetration Air Raids in the War of Attrition, 1969-1970." Journal of Contemporary History 19, no.3 (1984): 549-57.

Burns, William. Economic Aid and American Foreign Policy towards Egypt. Albany, NY: State University of NY, 1985.

Dallek, Robert. Nixon and Kissinger: Partners in Power. London: Allen Lane, 2007.

Eban, Abba. Pirkei Haiyim [Memoirs]. Tel Aviv: Sifriyat Ma'ariv, 1978.

El Hussini, Mohrez. Soviet-Egyptian Relations, 1945-1985. Houndmills and London: Macmillan, 1987.

Ferris, Jesse. Nasser's Gamble: How the Intervention in Yemen Caused the Six-Day War and the Decline of Egyptian Power. Princeton and Oxford: Princeton University Press, 2013.

Gat, Moshe. Britain and the Conflict in the Middle East, 1964-1967; the Coming of the Six-Day War. Westport, Connecticut, and London: Praeger, 2003.

Gawrych, George W. The Albatross of Decisive Victory: War and Policy between Egypt and Israel in the 1967 and 1973 Arab-Israeli Wars. Westport, Connecticut: Greenwood Press, 2000.

Gazit, Mordechai. Israeli Diplomacy and the Quest for Peace. London: Frank Cass, 2002.

Haber, Eitan. Ha-Yom Tifrots Milhama [Today War Will Break Out]. Tel Aviv: Idanim, 1987.

Heikal Mohamed. Road to Ramadan. London: Collins, 1975.

Heikal, Mohamed. Secret Channels: The Inside Story of Arab-Israeli Peace Negotiations. London: Harper and Collins, 1996.

Johnson, Lyndon, B. The Vantage Point: Perspective of the Presidency, 1963-1967. New York: Holt Reinhart and Winston, 1971.

Kissinger, Henry. Shnotai ba-Bayit ha-Lavan [The White House Years, vols. 1-3] Tel Aviv: Idanim, 1980.

Korn, David. A. Stalemate: The War of Attrition and Great Power Diplomacy in the Middle East, 1967-1970. Boulder: Westview Press, 1992.

Lundesta, Geir. East, West, North, South; Major Development in International Politics, 1945-1990. Oslo: Norwegian University Press, 1991.

Moore, John Morton. The Arab-Israeli Conflict. Princeton, NJ: Princeton University Press, 1973. 
Nixon, Richard M. The Memoirs of Richard Nixon. London: Arrow, 1979.

Parker, B. Richard. The Politics of Miscalculations in the Middle East. Bloomington: Indiana University Press, 1993.

Pedatzur, Reuben. Nitsahon ha-Mevukha:Mediniyut Yisra'el le-Ahar Milhemet Sheshet Ha-Yamim [A Triumph of Embarrassment: Israel and the Territories following the Six Day War]. Tel Aviv: Bitan, 1996.

Pollock, David. The Politics of Pressure: American Arms and Israeli Policy since the Six Day War. Westport, Connecticut: Greenwood Press, 1982.

Quandt, William B. Peace Process: American Diplomacy and the Arab-Israeli Conflict since 1967. Berkley, CA: University of California Press, 2001.

Rabin, Yitzhak. Pinkas Sherut [Service Notebook. Vols.1-2]. Tel Aviv: Sifriyat Ma'ariv, 1979.

Rafael, Gidon. Be-Sod Le'umim: Shloshim Shnot Mediniyut Huts, Mabat mi-Bifnim [Destination Peace: Three Decades of Israeli Foreign Policy]. Jerusalem: Idanim, 1981.

Riad, Mahmoud. Struggle for Peace in the Middle East. London: Quartet Books, 1981.

Rostow, Eugene, V. Peace in Balance: The Future of American Foreign Policy. New York, Simon, and Schuster, 1972.

Rubinstein, Alvin, Z. Red Star on the Nile; The Soviet-Egyptian Influence Relationship since the June War. Princeton, NJ: Princeton University Press, 1977.

Sadat, Anwar. In Search of Identity: An Autobiography. New York: Harper and Row, 1978.

Shannon, Vaughn P. Balancing Act: US Foreign Policy and the Arab-Israeli Conflict. Burlington, VT: Ashgate, 2003.

Sharnoff, Michael. Nasser's Peace; Egypt's Response to the 1967 War with Israel. New York: Routledge, 2017.

Shem-Tov, Victor, "Golda's Missed Opportunities: Thirty Year to the Yom Kippur War -A View from the Cabinet Table." [ in Hebrew.] Kivunim Hadashim, 10 (2004): 216-232.

Shiff, Ze'ev. Knafaim Me'al Ha-Suez; Sipuro Shel Hail Ha-Avir Be-Milhemet Ha-Hatasha [Phantom over the Nile: The Story of the Israeli Air-Corps] Haifa: Shikmona, 1970.

Spiegel, Steven, L. The Other Arab-Israeli Conflict: Making America's Middle East Policy from Truman to Reagan. Chicago Il: University of Chicago Press, 1985.

Stein, Kenneth, W. Heroic Diplomacy; Sadat, Kissinger, Carter, and the Quest for ArabIsraeli Peace. New York: Routledge, 1999.

Tschrigi, Dan. The American Search for Middle East Peace. Westport, Connecticut: Praeger, 1989.

Vitan, Ariel "The Soviet Military Presence in Egypt 1967-1972: A new Perspective." Journal of Slavic Military Studies, 8, no.3 (September 1995): 547-565.

Wehling, Fred. Irresolute Princes: Kremlin Decision-Making in the Middle East. Basingstoke: Macmillan, 1997. 
Ya'acobi, Gad. Hesed ha-Zman: Pirkei Otobiyografya [Grace of Time: An Autobiography]. Tel Aviv: Sifriat Chemed, 2002.

Yaqub, Salim. "The Politics of Stalemate: The Nixon Administration and the Arab-Israeli Conflict." in The Cold War in the Middle East: Regional Conflict and the Superpowers, 1967-1973, edited by Nigel J Ashton, 35-58. London: Routledge, 2007. 